Research Article

\title{
Pentoxifylline as a Therapy for Thin Endometrial Lining in Infertility
}

\author{
Pentoksifilin sebagai Terapi Endometrium Tipis pada Infertilitas \\ Muharam Natadisastra, Riyan H Kurniawan, Devi M Malik \\ Department of Obstetrics and Gynecology \\ Faculty of Medicine University of Indonesial \\ Dr. Cipto Mangunkusumo Hospital \\ Jakarta
}

\begin{abstract}
Objective: To evaluate the effect of pentoxifylline as a single regimen therapy for thin endometrial lining in infertility.

Method: A cross-sectional retrospective research was held in Yasmin Clinic - Kencana, Dr. Cipto Mangunkusumo Hospital from 2010 until 2011. Our respondents were women with infertility problem.

Result: There was significant improvement of endometrial lining in respondents who received pentoxifylline in the first month $(\mathrm{p}<0.0001)$.

Conclusion: There was significant improvement of endometrial lining after pentoxifylline therapy.

[Indones J Obstet Gynecol 2015; 3: 151-153]

Keywords: infertility, pentoxifylline, thin endometrium
\end{abstract}

\author{
Abstrak \\ Tujuan: Menilai efek pentoksifilin sebagai terapi tunggal untuk dinding \\ endometrium tipis pada masalab infertilitas. \\ Metode: Penelitian potong-lintang retrospektif dilakukan di Klinik \\ Yasmin - RSCM Kencana sejak 2010 sampai 2011. Responden meru- \\ pakan perempuan dengan permasalahan infertilitas. \\ Hasil: Terdapat peningkatan tebal endometrium pada responden yang \\ mendapat pentoksifilin pada bulan pertama $(p<0,0001)$. \\ Kesimpulan: Terdapat perbaikan bermakna pada dinding endometrium \\ setelab terapi pentoksifilin. \\ [Maj Obstet Ginekol Indones 2015; 3: 151-153] \\ Kata kunci: endometrium tipis, infertilitas, pentoksifilin
}

Correspondence: R. Muharam Natadisastra. Division of Reproductive Immunoendocrinology, Department of Obstetrics and Gynecology, Faculty of Medicine University of Indonesia, Dr. Cipto Mangunkusumo General Hospital, Jakarta.

Telephone: +628161188027, email: rmuharam@yahoo.com.

\section{INTRODUCTION}

Success rate of in vitro fertilization depends on two main things, namely the quality of the embryo and the atmosphere of endometrium during implantation. Endometrium has two phases during each menstrual cycle, which are proliferative and secretion phase. ${ }^{1}$ Physiologic changes in endometrial lining consists of increased functional layer thickness and increased spiral artery to prepare for implantation. If those changes fail to achieve pregnancy, menses occur. ${ }^{2,3}$ Therefore, to facilitate a successful pregnancy, an adequate growth of endometrium is necessary. 3,4

Several literatures stated the presence of a significant relation between endometrial thickness with pentoxifylline (PTX) therapy, however some failed to show the effect. The thickness of endometrial lining will improve the success rate of pregnancy in assisted reproductive technology (ART). ${ }^{1,5}$
PTX is a phosphodiesterase inhibitor derived from methylxanthine, a vasodilating chemical substance which can induce morphologic changes in erythrocytes, prevent inflammation process, and reduce blood viscosity by preventing platelet aggregation process and increasing concentration of intracellular cyclic nucleotide. ${ }^{6-9}$ Currently, PTX is used as therapy for vascular problems, such as intermittent claudication, ischemic ulcers and many more. ${ }^{8}$

This research was performed to evaluate the significance of improvement in endometrial lining with PTX as a single regimen therapy. In many developed countries, PTX has entered clinical trials with placebo, providing a variety of results. Nowadays, ART is beginning to develop in Indonesia, thus it is considered important to perform a direct evaluation of PTX. 


\section{METHODS}

This study was carried out in cross sectional design involving 22 respondents, and took place in Yasmin Clinic Kencana, Dr. Cipto Mangunkusumo Hospital from 2010 to 2011. Target population for this study was patients presenting for infertility problems to Yasmin Clinic and fulfilled the inclusion criteria. Inclusion criteria for our study were women who agreed to join the study, patients with infertility, and patients with endometrial thickness $<6$ $\mathrm{mm}$; while our exclusion criteria were those who had pelvic inflammatory disease. We defined thin endometrium as a condition where the functional layer of endometrium during the secretory phase is less than $6 \mathrm{~mm}$ in thickness, while no hormonal imbalance or infections were identified from our examinations.

Endometrial thickness was assessed using transvaginal ultrasound at mid-luteal phase by a single operator. The assessment was performed at baseline before PTX therapy administration, then the patient's endometrial thickness was reassessed in the second and third month after receiving PTX continuously.

\section{RESULT}

Of the twenty-two samples collected, we found that the patients' age ranged from 29 to 44 years, with a median of 36 years old. Most of the samples (9.41\%) had unexplained infertility, whereas we also identified other causes such as endometrial polyps $(1.5 \%)$, IVF failure $(1.4 \%)$, and polycystic ovaries $(1.5 \%)$.

Table 1. Age Characteristic Description

\begin{tabular}{lc}
\hline \hline \multicolumn{1}{c}{ Patient age characteristic $(\mathbf{n}=\mathbf{2 2})$} & age $($ year $)$ \\
\hline Median & 36 \\
Minimum & 29 \\
Maximum & 44 \\
\hline \hline
\end{tabular}

The endometrial thickness in the first month before administration of PTX ranged between 2.8-5 $\mathrm{mm}$ with a median value of $5 \mathrm{~mm}$; while in the second month, the range is increased to $4-14 \mathrm{~mm}$ with a median value of $7.0 \mathrm{~mm}$; and in the third month ranged between $4-12 \mathrm{~mm}$ with a median value of $8.0 \mathrm{~mm}$. According to statistical calculations with repeated measure method (Friedman), we obtained a p-value of $<0.0001$, which shows the significance between endometrial thickness before and after PTX therapy. The study shows that endometrial thickness increased in 18 respondents $(82 \%)$ in the second month, and continued to increase in 9 respondents $(41 \%)$ in the third month, while 1 respondent experienced decrease in thickness. For endometrial thickness in the second month compared to the previous month in which the patient has not received PTX treatment, we obtained a p-value $<0.0001$; and for the third month to the second month, we obtained p-value $<0.0001$.

In the first month of PTX therapy, 18 respondents $(82 \%)$ experienced an increase in endometrial thickness and four respondents $(18 \%)$ showed no change in endometrial thickness. Meanwhile, in the second to third months, nine respondents (41\%) showed improvement of endometrial lining, 12 respondents had no change, and one respondent $(5 \%)$ actually had declining endometrial thickness.

Table 3. Endometrial Thickness Change in the First, Second and Third Month

\begin{tabular}{lcc}
\hline \hline & $\begin{array}{c}\mathbf{1}^{\text {st }} \text { and 2nd month } \\
\mathbf{n}(\%)\end{array}$ & $\begin{array}{c}2^{\text {nd }} \text { and } 3^{\text {rd }} \text { month } \\
\mathbf{n}(\%)\end{array}$ \\
\hline Increase & $18(82)$ & $9(41)$ \\
No change & $4(18)$ & $12(54 \%)$ \\
Decrease & $0(0)$ & $1(5 \%)$ \\
\hline \hline
\end{tabular}

We encountered adverse effect in three patients, with nausea and dizziness at the first week after using pentoxyphiline. After receiving education and observation, after two weeks the symptoms disappeared.

Table 2. Endometrial Thickness in the First Month of Therapy (not yet receiving PTX), Second and Third Month (after receiving PTX)

\begin{tabular}{lcccc}
\hline \hline & $1^{\text {st }}$ month & $2^{\text {nd }}$ month & $3^{\text {rd }}$ month & p-value \\
\hline Endometrial thickness $(\mathrm{mm})($ median$[$ min-max $])$ & $5(2.8-5)$ & $7(4-14)$ & $8(4-12)$ & $<0.0001$ \\
\hline \hline
\end{tabular}




\section{DISCUSSION}

The results obtained from our study, demonstrate the significance of the relationship between endometrial thickness before and after PTX therapy. This can be explained because PTX supplementation may increase cAMP function and decrease levels of TNF- $\alpha$ which may improve the process of implantation. Administration of PTX also results in increased flexibility and decreased erythrocyte aggregation of platelets, thereby increasing blood flow to the small capillaries in the endometrium, the result of which can be assessed from the thickness of the endometrium.

PTX as a therapy regimen may provide potential improvements affecting microvascularization, thus repairing thin endometrium and also improving tissue oxygenation.

\section{CONCLUSION}

PTX therapy significantly increases endometrial thickness in patients with thin endometrium. PTX can be used to improve the thickness of the endometrium in these patients.

\section{REFERENCES}

1. Basil S. Changes in endometrial thickness, width, length and pattern in predicting pregnancy outcome during ovarian stimulation in in vitro fertilization. Ultrasound Obstet Gynecol 2001; 18: 258-63.

2. Cunningham FG, Leveno KJ, Bloom SL, Hauth JC, Rouse DJ, editor. Williams Obstetrics. $23^{\text {rd }}$ ed. United States of America: The McGraw-Hill Companies Inc; 2010: 36-43.

3. Paulson RJ. Hormonal induction of endometrial receptivity. Fertil Steril 2011; 96: 530-5.

4. Takasaki A, Tamura H, Miwa I, et al. Endometrial growth and uterine blood flow: a pilot study for improving endometrial thickness in the patients with a thin endometrium. Fertil Sterility 2008; 93: 1851-5

5. Aleyasin MA, Mohseni M, Mahdavi A. Effects of pentoxifylline and vitamin $\mathrm{E}$ on pregnancy rate in infertile women treated by ZIFT: a randomized clinical trial. Iran J Reprod Med 2009; 7(4): 175-9.

6. Ledee-Bataille FO, Lefaix J-L, Chaouat G, et al. Combined treatment by pentoxifylline and tocopherol for recipient women with a thin endometrium enrolled in an oocyte donation programme. Hum Reprod 2002; 17(5): 1249-53.

7. Shaw SM, Shah MKH, Simon GW, et al. Immunological mechanism of pentoxifylline in chronic heart failure. Eur J Heart Failure 2008; 11: 113-8.

8. Windmeir C, Gressner AM. Pharmacological aspects of pentoxifylline with emphasis on its inhibitory actions on hepatic fibrogenesis. Gen Pharmas 1997; 29: 181-96.

9. Bruno RB, Marques TF, Barista TMT, et al. Pentoxifylline treatment improves neurological and neurochemical deficits in rats subjected to transient brain ischemia. Brain Research 2009: 55-64. 